\title{
Amalan Pentaksiran Berasaskan Produksi Bagi Kursus Bangsawan Di Sebuah Akademi Seni
}

\author{
Rime Nazren Abd Razak \\ Akademi Seni Budaya dan Warisan Kebangsaan (ASWARA) \\ e-mail: rime@aswara.edu.my
}

Diterbitkan dalam talian: 26 Jun 2020

Cite this paper (APA): Razak, R. N. A. (2020). Amalan pentaksiran berasaskan produksi bagi kursus Bangsawan di sebuah akademi seni. Jurai Sembah, 1(1), 8-24. https://doi.org/10.37134/juraisembah.vol1.1.2.2020

\begin{abstract}
Abstrak
Kajian ini bertujuan untuk meneliti aktiviti, kaedah dan instrumen pentaksiran menerusi tajuk Amalan Pentaksiran Berasaskan Produksi bagi Kursus Bangsawan di sebuah Akademi Seni. Seramai 20 orang responden kajian yang terdiri daripada 10 orang pelajar kursus Bangsawan, lima orang tenaga pengajar kursus Bangsawan dan lima orang pakar bidang dipilih melalui teknik pensampelan bertujuan. Kajian ini akan menggunakan Model Penilaian Kurikulum KIPP oleh Stufflebeam \& Coryn (2014) bagi meneliti keseluruhan perjalanan pentaksiran secara berperingkat di dalam produksi yang mana melalui empat komponen KIPP iaitu konteks, input, proses dan produk. Teori Taksonomi Bloom (1956) dipraktikkan untuk melihat amalan pentaksiran berdasarkan objektif pembelajaran dan kriteria Metarubrik oleh Arter \& McTighe (2001) digunakan untuk menganalisis dokumen rubrik produksi Bangsawan. Pengumpulan data secara pemerhatian dan temu bual dianalisis secara tematik bagi menemui hasil dapatan yang bersesuaian. Hasil kajian ini mempunyai dua implikasi. Dari sudut teoretis, kajian ini berjaya menggabungkan model penilaian kurikulum dengan teori objektif pengajaran dalam semakan pentaksiran produksi Bangsawan. Manakala dari sudut amalan, kajian ini menyediakan tatacara perlaksanaan pentaksiran secara tersusun mengikut kategori di dalam peringkat pentaksiran produksi Bangsawan. Oleh itu, kajian ini menyumbang kepada ilmu baru di dalam bidang kurikulum pendidikan terutama yang melibatkan pendidikan seni persembahan di Malaysia.
\end{abstract}

Kata kunci: bangsawan, model penilaian kurikulum, pentaksiran produksi, rubrik

\begin{abstract}
This study aims to examine the activities, methods, and instruments of assessment through the title of ProductionBased Assessment Practice for Bangsawan Courses at an Academy of Art. A total of 20 respondents of the study consisting of 10 Bangsawan course students, five Bangsawan course lecturers, and five field experts were selected through targeted sampling techniques. The research applies a KIPP curriculum evaluation model by Stufflebeam \& Coryn (2014) is used to study the entire process of assessment in stages through which four components of KIPP are context, input, process, and product. Therefore, Bloom Taxonomy (1956). theory was applied to view assessment practices based on learning objectives and Metarubric criteria by Arter \& McTighe (2001) were used to analyze Bangsawan rubric production documents. Observational data and interviews were thematically analyzed to find the appropriate results. The results of this study have two implications. From a theoretical point of view, this study successfully integrates the curriculum assessment model with the teaching objective theory in assessing the assessment of the production of the Bangsawan. Where as in practice, this study provides procedures for categorically implementing the assessment in the assessment stage of the production of the Bangsawan. Therefore, this study contributes to new knowledge in the field of education curriculum especially involving performing arts education in Malaysia.
\end{abstract}

Keywords: bangsawan, curriculum evaluation model, production based assessment, rubric 


\section{Pengenalan}

Pentaksiran adalah salah satu kaedah dalam penilaian yang diterapkan bagi menguji tahap pencapaian pelajar dalam pembelajaran. Lembaga Peperiksaan Malaysia (2000) menjelaskan pentaksiran adalah sebagai satu pembelajaran yang merangkumi aktiviti menghurai, mengumpul, merekod, memberi skor dan menterjemah maklumat tentang pembelajaran seseorang pelajar bagi sesuatu tujuan tertentu. Noraini Idris (2010) menyatakan bahawa pentaksiran dirancang dan dikendalikan oleh pengajar untuk menjadi sebahagian daripada proses pengajaran yang diharapkan mampu memperbaiki proses pengajaran terhadap pelajar. Menurutnya lagi, pentaksiran ialah sebagai pembelajaran bagi menggalakkan seorang pengajar menggunakan kebijaksanaan untuk menilai kefahaman pelajar dalam proses pembelajaran dan pengajaran dijalankan. Oleh yang demikian, aspek pentaksiran ini dilihat oleh pengkaji untuk mengukur kebolehpercayaan dan kesahan pada kursus Bangsawan yang merupakan salah satu kursus teras di Akademi Seni, Budaya dan Warisan Kebangsaan (ASWARA). Kursus ini bersifat praktikal yang mana kerja-kerja produksi diajar kepada semua pelajar melalui tiga peringkat utama iaitu praproduksi, produksi dan pascaproduksi. Di peringkat praproduksi, pelajar diajar untuk melaksanakan kerja pengurusan, kerja kreatif dan lakonan. Manakala di peringkat produksi, pelajar akan melaksanakan kerja pementasan iaitu persembahan Bangsawan. Seterusnya pelajar akan melalui peringkat terakhir iaitu pascaproduksi. Di sinilah peringkat post-mortem atau pemurnian akan dilakukan. Setiap pelajar akan memberi maklum balas berkenaan produksi yang telah dilaksanakan. Sepanjang tempoh pembelajaran, setiap pelajar akan diberi penilaian oleh pengajar kursus yang dilantik. Penilaian ini lebih bersifat pentaksiran berasaskan produksi, kerana penilaian tersebut melalui tiga peringkat yang telah dinyatakan.

\section{Latar Belakang Kajian dan Permasalahan Kajian}

Terdapat isu yang melibatkan penilaian terhadap kursus yang bersifat produksi sebegini. Pengaruh intuisi (naluri), ketidakseimbangan atau bias, dan kebolehpercayaan sering mengundang permasalahan apabila melakukan penilaian. Pengajar dilihat menghadapi kesukaran apabila ingin membuat keputusan dengan tepat. Dalam hal ini, sukar untuk membuat penilaian bagi perkara yang bersifat subjektif. Oleh itu, pengkaji ingin melihat sejauh mana pentaksiran berasaskan produksi ini dilaksanakan di ASWARA. Bagi menentukan keberkesanan rubrik, pemilihan kursus Bangsawan adalah bersesuaian kerana kursus tersebut memiliki kesempurnaan pembelajaran yang berorientasikan produksi. Secara ringkas Bangsawan merupakan pementasan teater tradisional Malaysia yang mempunyai beberapa struktur elemen penting sebagai repertoir iaitu; lakonan bangsawan, adat istiadat, struktur penyusunan latar, tarik nasib, tasmat dan sebagainya. Justeru itu, isu pentaksiran perlu dilihat sebagai suatu kajian yang penting bagi menentukan garis ukur yang standard dan sistematik agar faktor-faktor kelemahan seperti penilaian secara intuisi dan bias dapat diatasi. Dalam hal ini, intuisi dan bias merujuk kepada kemurahan hati individu yang berkepentingan seperti pengajar dalam meletakkan penilaian berdasarkan rasa atau naluri semata-mata. Oleh itu, kursus produksi Bangsawan yang bersifat subjektif ini dilihat mempunyai potensi kepada faktor kelemahan yang berlaku ke atas pengajar mahupun pelajar. Bagi perspektif pengajar, kesukaran yang dihadapi adalah untuk meletakkan markah bagi tahap pencapaian pelajar berdasarkan penilaian praktikal. Dalam hal ini, indikator menguasai sesuatu tahap ilmu sukar ditentukan kerana terpengaruh dengan latar belakang pelajar yang diketahui oleh pengajar menyebabkan intuisi atau bias boleh terjadi. Manakala bagi perspektif pelajar, isu bias atau intuisi ini dilihat melalui pemberatan penilaian kepada pelajar yang tidak seimbang terutama dalam aspek lakonan. Sejauh mana peranan watak utama dengan peranan watak pembantu setara untuk dinilai dalam satu produksi. Tentunya wujud delima dalam menentukan markah bagi penilaian tersebut.

\section{Objektif dan Soalan Kajian}

Objektif kajian ini adalah seperti berikut:

i. Menerokai permasalahan yang dihadapi oleh pengajar dan pelajar dalam kaedah pentaksiran berasaskan produksi.

ii. Mengetahui pendapat pakar berkenaan kaedah yang bersesuaian dengan pentaksiran berasaskan produksi.

iii. Mengenal pasti kriteria rubrik yang digunakan dalam pentaksiran berasaskan produksi. 
Oleh yang demikian, kajian ini akan menjawab tiga soalan kajian iaitu:

i. Apakah kekangan masalah yang dihadapi dalam proses pentaksiran berasaskan produksi oleh pengajar dan pelajar?

ii. Apakah pandangan pakar terhadap kaedah pentaksiran yang digunakan?

iii. Apakah kriteria rubrik yang digunakan di dalam pentaksiran berasaskan produksi?

\section{Metodologi Kajian}

Kajian ini dijalankan dengan mengaplikasikan pendekatan kajian kes terhadap kursus Bangsawan yang merupakan salah satu kursus teras di Akademi Seni Budaya dan Warisan Kebangsaan (ASWARA). Kajian kes ini merupakan pendekatan yang sinonim dengan penyelidikan kualitatif. Penyelidikan kualitatif mempunyai ciri populasi dan sampel yang mudah dikendalikan. Hal ini dapat dilihat berdasarkan saiz sampel yang digunakan dalam kajian ini adalah kecil, pensampelan yang ada bukannya kebarangkalian dan pilihan sampel bertepatan dengan tujuan kajian. Pensampelan bertujuan (purposive sampling) merujuk kepada prosedur pensampelan di mana sekumpulan subjek yang mempunyai ciri-ciri tertentu dipilih sebagai responden kajian (Chua Yan Piaw, 2011). Di dalam kajian ini, pengkaji telah menetapkan jumlah sampel yang kecil berdasarkan tiga kategori berbeza iaitu pakar bangsawan, pengajar dan pelajar. Ketiga-tiga kategori ini bertujuan untuk mendapatkan maklum balas berkenaan pentaksiran berasaskan produksi. Manakala format instrumen dalam memungut data tidak formal dan lebih bebas, tidak berstruktur, tidak ditetapkan dan subjektif. Keadaan ini menjadikan instrumen yang digunakan dalam kajian ini fleksibel dan memudahkan kutipan data dilakukan. Justeru itu, instrumen yang digunakan ini diaplikasikan untuk memungut data berdasarkan pemerhatian tidak berstruktur yang melibatkan pengkaji menggunakan tiga aspek triangulasi iaitu masa, ruang dan pemerhati. Berdasarkan aspek masa, pemerhatian dilakukan beberapa kali pada sela masa yang berlainan. Manakala aspek ruang pula, pemerhatian dilakukan beberapa kali pada tempat atau keadaan yang berlainan.

\section{Kerangka Kajian}

Kerangka konseptual direka bagi mempermudah pengkaji melihat kesepaduan struktur kajian dalam mendapatkan hasil dapatan yang diingini. Terdapat empat bahagian di dalam kerangka konseptual yang telah dikemukakan iaitu Amalan Pentaksiran berasaskan produksi bagi kursus Bangsawan; Model Penilaian Kurikulum Konteks, Input, Proses, Produk (KIPP); Fasa Penilaian dan hasil dapatan penilaian kursus produksi Bangsawan. Perkara ini dapat dijelaskan menerusi Rajah 1 berikut;

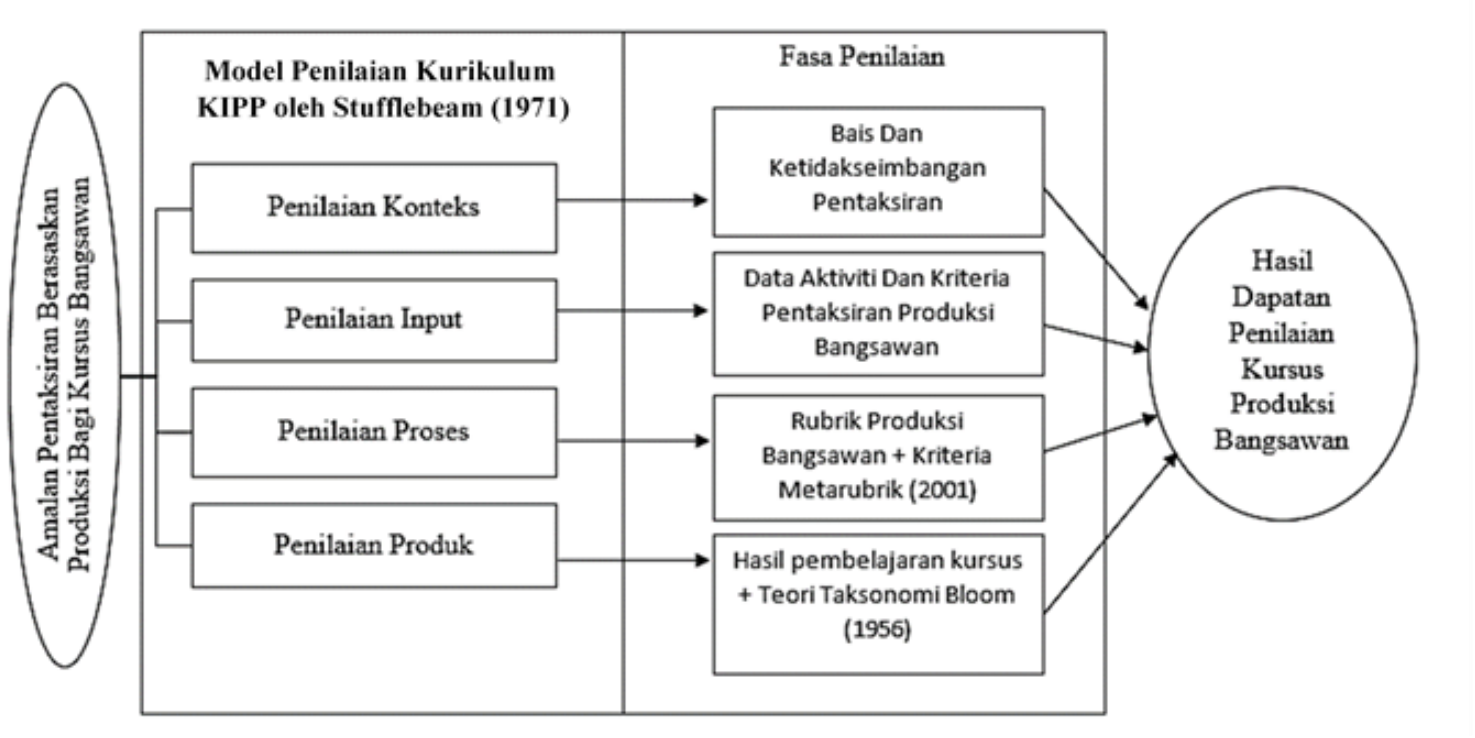

Rajah 1: Kerangka Konseptual Kajian Amalan Pentaksiran Berasaskan Produksi bagi Kursus Bangsawan.

Melalui kerangka konseptual ini dapatlah dinyatakan bahawa pengkaji menggunakan Model KIPP yang dikemukakan oleh Stufflebeam \& Coryn (2014) sebagai model penilaian. Terdapat empat komponen 
utama di dalam Model KIPP iaitu penilaian konteks, penilaian input, penilaian proses dan penilaian produk. Melalui komponen pertama iaitu "Konteks," penilaian ini tertumpu kepada isu dan masalah persekitaran yang dihadapi sepertimana yang dinyatakan dalam pernyataan masalah. Isu tersebut adalah berkaitan dengan bias dan ketidakseimbangan pentaksiran." Manakala penilaian di peringkat "Input," informasi dan maklumat berkaitan data aktiviti serta kriteria pentaksiran dalam kursus produksi Bangsawan dikumpul berdasarkan instrumentasi temu bual, pemerhatian dan semakan dokumen. Dalam hal ini terdapat dua jenis responden yang digunakan iaitu pengajar dan pelajar bagi tujuan mengenal pasti kebolehpercayaan dan kesahan dalam sesuatu isu. Seterusnya di peringkat penilaian "Proses," pengkaji menjalankan semakan terhadap dokumen penilaian yang digunakan dalam pentaksiran iaitu rubrik produksi Bangsawan. Berdasarkan rubrik tersebut, pengkaji akan meneliti kriteria rubrik yang digunakan sebagai alat pentaksiran berasaskan produksi. Oleh itu, proses ini meneliti kepada kandungan, kejelasan, kemudahan dan keadilan dalam membentuk kefahaman yang jelas berkaitan pentaksiran. Rujukan utama yang digunakan adalah kriteria Metarubrik yang diadaptasi menerusi Scoring Rubrics in the Classroom oleh Arter \& McTighe (2001). Bagi menentukan keutuhan semakan terhadap dokumen penilaian, lima orang responden pakar bidang terlibat langsung dalam melakukan peringkat penilaian proses di dalam komponen model KIPP. Manakala komponen penilaian produk, pengkaji mengaplikasikan teori pembelajaran iaitu teori Taksonomi Bloom dalam mengukur aras dan tahap kesukaran aktiviti pentaksiran yang menyokong kepada penguasaan hasil pembelajaran kursus bagi produksi Bangsawan. Dalam hal ini, domain pengajaran berperanan menentukan tahap kognitif, psikomotor dan afektif pelajar berdasarkan kriteria rubrik yang digunakan serta amalan pentaksiran oleh pengajar. Hasil daripada penilaian terhadap amalan pentaksiran kursus produksi Bangsawan ini, satu hasil dapatan kajian akan dikemukakan kepada pihak berkepentingan bagi melaksanakan langkah penambahbaikan dan pemurnian ke atas kursus tersebut.

\section{Tinjauan Literatur}

Berdasarkan tinjauan literatur yang diteliti oleh penyelidik, maka jurang kajian dapat dikenal pasti berdasar analisa kritikal seperti di Jadual 1.

Jadual 1: Ringkasan literatur (Analisis kritikal)

\begin{tabular}{|c|c|c|c|c|}
\hline Bil. & Penulis & $\begin{array}{l}\text { Dapatan kajian / } \\
\text { Metodologi }\end{array}$ & Instrumen / Sampel & Gap / Jurang \\
\hline 1. & $\begin{array}{l}\text { Rosman Ishak } \\
\text { (2014) } \\
\text { Model Pengajaran } \\
\text { Bangsawan } \\
\text { Berasaskan } \\
\text { Teknologi Digital } \\
\text { Di Sebuah } \\
\text { Akademi Seni }\end{array}$ & $\begin{array}{l}\text { - Kaedah pengajaran yang } \\
\text { sesuai dalam seni } \\
\text { persembahan bangsawan } \\
\text { - Strategi pengajaran } \\
\text { terkini yang dapat } \\
\text { dipraktikkan dalam } \\
\text { implementasi pengajaran } \\
\text { seni persembahan } \\
\text { bangsawan } \\
\text { - Reka bentuk model } \\
\text { pengajaran seni } \\
\text { persembahan } \\
\text { Bangsawan berasaskan } \\
\text { teknologi digital } \\
\text { mengikut pendekatan } \\
\text { Interpretive Structure } \\
\text { Model (ISM) }\end{array}$ & $\begin{array}{ll}\text { - } & \text { Pendekatan } \\
\text { Interpretive } \\
\text { Structural } \\
\text { Modeling (ISM) } \\
\text { - } \\
\text { Responden kajian } \\
\text { terdiri daripada } 22 \\
\text { orang pakar yang } \\
\text { terlibat }\end{array}$ & 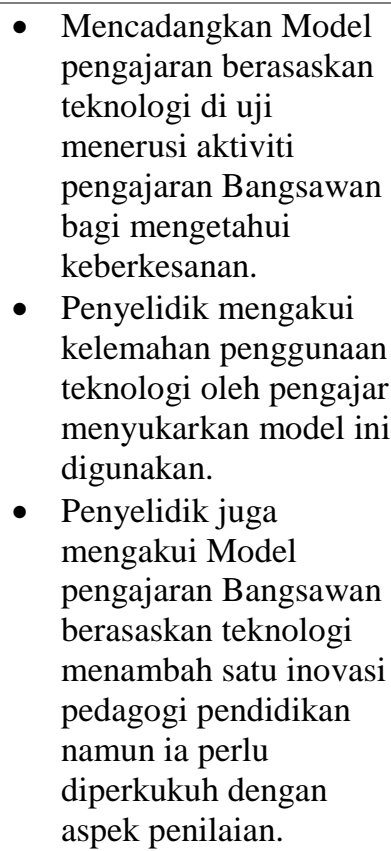 \\
\hline 2. & $\begin{array}{l}\text { Ozaki, C.C., } \\
\text { Worley, D., Cherry, } \\
\text { E. (2015). }\end{array}$ & $\begin{array}{l}\text { - Kajian ini menggunakan } \\
\text { kerangka kajian Gale \& } \\
\text { Bond's }\end{array}$ & $\begin{array}{ll}\text { - } & \text { Pendekatan Soal } \\
\text { Selidik } \\
\text { - } \\
\text { Keperluan soal } \\
\text { selidik bertujuan }\end{array}$ & $\begin{array}{l}\text { Kerangka kajian ini } \\
\text { dapat menjelaskan } \\
\text { pengetahuan, kreativiti } \\
\text { produksi. hubungan }\end{array}$ \\
\hline
\end{tabular}




\begin{tabular}{|c|c|c|c|c|}
\hline Bil. & Penulis & $\begin{array}{l}\text { Dapatan kajian / } \\
\text { Metodologi }\end{array}$ & Instrumen / Sampel & Gap / Jurang \\
\hline & $\begin{array}{l}\text { Assessing the } \\
\text { Work: An } \\
\text { Exploration of } \\
\text { Assessment in the } \\
\text { Musical Theatre } \\
\text { Arts. RPA Journal, } \\
\text { Research And } \\
\text { Practice In } \\
\text { Assessment, Vol.10, } \\
\text { 12-24. }\end{array}$ & $\begin{array}{l}\text { - Berdasarkan kajian } \\
\text { tersebut, penilaian } \\
\text { terhadap Muzikal Teater } \\
\text { dilihat menerusi perkara } \\
\text { berikut: } \\
\text { (1) Perkembangan } \\
\text { pengetahuan, } \\
\text { (2) Membina kreativiti } \\
\text { produksi. } \\
\text { (3) Hubungkait } \\
\text { kontekstual, } \\
\text { (4) Kemahiran } \\
\text { Komunikasi }\end{array}$ & $\begin{array}{l}\text { mengumpul data } \\
\text { bagi mengenal } \\
\text { pasti maklumbalas } \\
\text { pelajar dan } \\
\text { golongan industri } \\
\text { berkaitan } \\
\text { pembelajaran } \\
\text { Muzikal Teater. } \\
\text { Tumpuan kajian } \\
\text { melibatkan } 48 \\
\text { institusi } \\
\text { pendidikan tinggi } \\
\text { yang menawarkan } \\
\text { Diploma Seni dan } \\
\text { Diploma Seni } \\
\text { Persembahan } \\
\text { dalam bidang } \\
\text { muzikal teater di } \\
\text { Amerika Syarikat. }\end{array}$ & $\begin{array}{l}\text { kontekstual dan } \\
\text { Kemahiran } \\
\text { Komunikasi dengan } \\
\text { tersusun. } \\
\text { - Namun penyelidik } \\
\text { mendapati garis ukur } \\
\text { penilaian tidak } \\
\text { mengambarkan situasi } \\
\text { pembelajaran sebenar } \\
\text { kerana industri seni } \\
\text { adalah berbeza dengan } \\
\text { pendidikan seni yang } \\
\text { melibatkan sistem } \\
\text { pendidikan formal. }\end{array}$ \\
\hline 3. & $\begin{array}{l}\text { Nurfirdawati } \\
\text { Muhamad Hanafi } \\
\text { (2016) } \\
\text { Pembangunan dan } \\
\text { penentusahan } \\
\text { rubrik pentaksiran } \\
\text { prestasi } \\
\text { Bagi menaksir } \\
\text { projek reka bentuk } \\
\text { seni bina } \\
\text { di politeknik } \\
\text { Malaysia }\end{array}$ & $\begin{array}{l}\text { - } \text { Model ADDIE dan } \\
\text { Kerangka } \\
\text { Pembangunan Rubrik } \\
\text { - Penggunaan } \\
\text { pendekatan Model } \\
\text { Pengukuran Rasch } \\
\text { Pelbagai Faset } \\
\text { (MFRM) menunjukkan } \\
\text { rubrik yang dibina } \\
\text { mempunyai kesahan } \\
\text { kandungan yang tinggi } \\
\text { dalam menaksir projek } \\
\text { reka bentuk seni bina di } \\
\text { Politeknik. }\end{array}$ & $\begin{array}{l}\text { - } \begin{array}{l}\text { Pengujian alfa } \\
\text { (rintis) dan }\end{array} \\
\text { pengujian beta } \\
\text { (sebenar). } \\
\text { - } \\
\text { Data ujian rintis } \\
\text { (pengujian alfa) } \\
\text { dianalisis } \\
\text { menggunakan } \\
\text { pendekatan Model } \\
\text { Rasch } \\
\text { Pengujian beta } \\
\text { dilaksanakan di } \\
\text { tiga buah } \\
\text { politeknik, } \\
\text { melibatkan 136 } \\
\text { pelajar semester } 5 \\
\text { dan } 48 \text { pemeriksa } \\
\text { (19 pensyarah dan } \\
29 \text { rakan pelajar). }\end{array}$ & $\begin{array}{l}\text { Penyelidik } \\
\text { mencadangkan supaya } \\
\text { kajian bias dilakukan } \\
\text { memandangkan ralat } \\
\text { pengukuran yang } \\
\text { disumbangkan oleh } \\
\text { rakan pelajar adalah } \\
\text { lebih tinggi berbanding } \\
\text { pensyarah }\end{array}$ \\
\hline 4. & $\begin{array}{l}\text { Nur Afifah Vanitha } \\
\text { Binti Abdullah } \\
\text { (2009) } \\
\text { Perkembangan Dan } \\
\text { Perubahan } \\
\text { Persembahan } \\
\text { Bangsawan Di } \\
\text { Sarawak, 1914- } \\
2004\end{array}$ & $\begin{array}{l}\text { - Teori Persembahan } \\
\text { Richard Schechner } \\
\text { - Faktor persekitaran } \\
\text { memainkan } \\
\text { Peranan penting dalam } \\
\text { mempengaruhi } \\
\text { production mode dan } \\
\text { proses persembahan } \\
\text { yang kemudiannya } \\
\text { mengakibatkan jatuh } \\
\text { bangunnya bangsawan } \\
\text { di Sarawak. }\end{array}$ & $\begin{array}{l}\text { - Primary research, } \\
\text { kaedah temu bual } \\
\text { dan content } \\
\text { analysis } \\
\text { - Tiga kategori } \\
\text { responden iaitu } \\
\text { tokoh-tokoh } \\
\text { budayawan, } \\
\text { penggiat-penggiat } \\
\text { teater Bangsawan } \\
\text { dan para peminat } \\
\text { serta penonton } \\
\text { persembahan } \\
\text { Bangsawan di } \\
\text { Sarawak. }\end{array}$ & $\begin{array}{l}\text { Penyelidik mengakui } \\
\text { perlu ada kajian } \\
\text { lanjutan tentang } \\
\text { peringkat produksi } \\
\text { yang menyokong } \\
\text { kepada sistem } \\
\text { production mode. }\end{array}$ \\
\hline 5. & $\begin{array}{l}\text { Marlenny } \\
\text { Deenerwan, } \\
(2018)\end{array}$ & $\begin{array}{ll}\text { - } & \text { Model PaR Robin } \\
\text { Nelsen - tiga prinsip }\end{array}$ & $\begin{array}{l}\text { - Kajian lapangan } \\
\text { dan menganalisis } \\
\text { konvensi }\end{array}$ & $\begin{array}{l}\text { - Penyelidik mengakui } \\
\text { terdapat kekurangan } \\
\text { dalam menghurai }\end{array}$ \\
\hline
\end{tabular}




\begin{tabular}{|c|c|c|c|c|}
\hline Bil. & Penulis & $\begin{array}{l}\text { Dapatan kajian / } \\
\text { Metodologi }\end{array}$ & Instrumen / Sampel & Gap / Jurang \\
\hline & $\begin{array}{l}\text { Mengetahui dan } \\
\text { Menguasai } \\
\text { Pengalaman: } \\
\text { Sebuah Proses } \\
\text { Pelaksanaan } \\
\text { Penyelidikan } \\
\text { Berasaskan } \\
\text { Persembahan }\end{array}$ & $\begin{array}{l}\text { iaitu: know how, know } \\
\text { what, dan know that } \\
\text { Tiga penemuan utama } \\
\text { dalam pelaksanaan } \\
\text { metodologi PaR } \\
\text { adalah merujuk kepada } \\
\text { seperti berikut: } \\
\text { (1) Kepentingan } \\
\text { mengetahui dan } \\
\text { menguasai } \\
\text { pengalaman praktikal } \\
\text { untuk membolehkan } \\
\text { ilmu pengetahuan } \\
\text { diintegrasikan ke } \\
\text { dalamnya. } \\
\text { (2) Kepentingan } \\
\text { refleksi dalam proses } \\
\text { pembinaan ilmu } \\
\text { pengetahuan, serta } \\
\text { (3) Memunculkan } \\
\text { aspek intelektual yang } \\
\text { selama ini terkandung } \\
\text { dalam sesebuah } \\
\text { pengalaman praktikal. }\end{array}$ & $\begin{array}{l}\text { Bangsawan yang } \\
\text { diamalkan oleh } \\
\text { Rahman B. } \\
\text { - Projek } \\
\text { persembahan } \\
\text { Bangsawan } \\
\text { Hikayat Seribu } \\
\text { Satu Malam } \\
\text { (1) Praproduksi } \\
\text { (penyelidikan, } \\
\text { pertemuan, rekaan, } \\
\text { perancangan) } \\
\text { (2) Produksi } \\
\text { (latihan, } \\
\text { pembangunan, dan } \\
\text { persembahan } \\
\text { akhir) } \\
\text { (3) Pascaproduksi } \\
\text { (refleksi dan } \\
\text { perancangan } \\
\text { penambahbaikan) }\end{array}$ & $\begin{array}{l}\text { proses kerja produksi } \\
\text { dalam konteks } \\
\text { pekerjaan seni. }\end{array}$ \\
\hline
\end{tabular}

Berdasarkan analisis daripada Jadual 1 yang dipaparkan, pengkaji dapat merumuskan bahawa masih terdapat jurang yang memerlukan kajian lanjut bagi memperjelaskan lagi penyelidikan tentang amalan pentaksiran berasaskan produksi. Setelah meneliti setiap kajian yang telah dilakukan, ternyata kajian terhadap Bangsawan telah banyak dilaksanakan sebagai satu sumber rujukan akademik. Perkara yang dikaji kebanyakannya tertumpu kepada sejarah dan perkembangan Bangsawan, struktur Bangsawan, pembelajaran Bangsawan dan estetika Bangsawan. Dalam hal ini, pengkaji merasakan isu tentang pentaksiran di dalam produksi Bangsawan juga bermanfaat untuk dijadikan bahan kajian kerana sumbangannya dapat menyelesaikan isu bias dan penilaian yang tidak seimbang. Secara tidak langsung kajian ini dapat menilai sejauh mana keberkesanan pentaksiran yang berasaskan produksi dalam konteks Bangsawan.

\section{Skop Kajian}

Kajian ini hanya akan menumpukan kepada peringkat pentaksiran yang menyentuh kepada tiga bahagian iaitu sebelum, semasa dan selepas. Di dalam pentaksiran berasaskan produksi, bahagian ini digelar sebagai praproduksi, produksi dan pascaproduksi. Pengkaji memilih bahagian ini adalah kerana potensi pengumpulan data adalah besar untuk mendapatkan maklumat berkenaan pentaksiran. Selain itu perkara yang nyatakan di dalam kerangka konseptual yang berkaitan dengan instrumentasi kajian adalah merujuk kepada sampel yang digunakan dalam mengumpul maklumat kajian. Dalam hal ini, terdapat tiga jenis responden iaitu pelajar, pengajar dan pakar bidang yang akan terlibat semasa sesi temu bual diadakan bagi mendapatkan pandangan dan komentar berkenaan amalan pentaksiran berasaskan produksi bagi kursus Bangsawan. Manakala dokumen penilaian yang digunakan di dalam amalan pentaksiran berasaskan produksi seperti skema penilaian dan rubrik produksi Bangsawan dianalisis bagi tujuan kajian. Sehubungan itu, peranan pensampelan ini adalah selari dengan objektif kajian yang mana bertujuan untuk mendapat maklumat dan input berkaitan objektif kajian iaitu menerokai permasalahan yang dihadapi oleh pelajar dan pengajar dalam kaedah pentaksiran berasaskan produksi. Manakala responden pakar bidang diperlukan untuk melengkapkan objektif seterusnya iaitu mengenal pasti pendapat pakar berkenaan kaedah yang bersesuaian dengan pentaksiran berasaskan produksi. Semakan dokumen penilaian juga adalah selari dengan objektif terakhir kajian iaitu bertujuan untuk mengenal pasti kriteria rubrik yang digunakan dalam pentaksiran berasaskan produksi. Berdasarkan kajian ini, pengkaji telah menentukan lingkungan lokasi yang 
ingin digunakan sebagai sumber pengumpulan data. Dalam hal ini, pengkaji memilih kampus Akademi Seni Budaya Dan Warisan Kebangsaan (ASWARA) yang berada di Wilayah Persekutuan Kuala Lumpur. Kampus ini merupakan satu-satunya institusi pengajian tinggi di bawah Kementerian Pelancongan, Seni dan Budaya Malaysia yang menawarkan pengajian sepenuh masa dalam bidang seni persembahan secara formal. Justeru itu, pengkaji telah menetapkan responden kajian seperti mana mengikut Jadual 2 di bawah:

Jadual 2: Responden kajian

\begin{tabular}{cl}
\hline Bil. & Responden kajian \\
\hline 1. & $\begin{array}{l}\text { Beberapa pelajar Akademi Seni Budaya dan Warisan Kebangsaan (ASWARA) yang mengambil kursus } \\
\text { Bangsawan. }\end{array}$ \\
\hline 2. & $\begin{array}{l}\text { Beberapa pelajar Akademi Seni Budaya dan Warisan Kebangsaan (ASWARA) yang mengambil kursus } \\
\text { Bangsawan. }\end{array}$ \\
\hline 3. & Pakar Bangsawan yang melibatkan pakar rujuk yang terdiri daripada tokoh dan pakar akademik. \\
\hline
\end{tabular}

\section{Analisis dan Dapatan}

Proses pengumpulan data dari hasil kajian kes yang dilaksanakan adalah menerusi temu bual, pemerhatian, kajian perpustakaan dan dokumen penilaian iaitu rubrik Bangsawan. Oleh itu analisis ini akan menjawab soalan kajian berdasarkan penghuraian data menerusi Model Penilaian KIPP yang dinilai secara deskriptif terhadap penilaian konteks, penilaian input, penilaian proses dan penilaian produk.

\section{Dapatan Data: Analisis Pendekatan Model Penilaian KIPP}

Berlandaskan Model Penilaian KIPP, terdapat empat komponen utama yang digunakan dalam menilai tentang amalan pentaksiran berasaskan produksi bagi kursus Bangsawan di sebuah Akademi Seni iaitu penilaian konteks, penilaian input, penilaian proses dan penilaian produk. Oleh yang demikian, dapatan data yang dikumpul menerusi temu bual, pemerhatian dan semakan dokumen pentaksiran dianalisis berdasarkan persoalan kajian yang telah dikemukakan. Secara ringkasnya penilaian konteks tertumpu kepada dapatan data yang berkaitan dengan persoalan kajian iaitu kekangan masalah yang dihadapi dalam proses pentaksiran dengan menggunakan data temu bual pengajar dan pelajar kursus Bangsawan. Manakala penilaian input melihat kepada kaedah pentaksiran yang digunakan di dalam kursus Bangsawan dengan menggunakan data temu bual pakar, pemerhatian dan semakan dokumen pentaksiran. Seterusnya penilaian proses akan menganalisis amalan pentaksiran berdasarkan produksi melalui data dokumen pentaksiran iaitu rubrik Bangsawan. Di peringkat ini, pakar bidang dapat melihat kekuatan dan kelemahan dokumen tersebut berpandukan jadual semakan Metarubrik yang telah disediakan. Dan akhir sekali adalah penilaian produk yang mana keseluruhan pentaksiran dilihat secara holistik berdasarkan perkara yang ingin dicapai menerusi hasil pembelajaran kursus Bangsawan dengan penjelasan berkaitan aras penguasaan Taksonomi Bloom. Gambaran pengisian komponen Model penilaian KIPP adalah seperti Rajah 2 berikut:

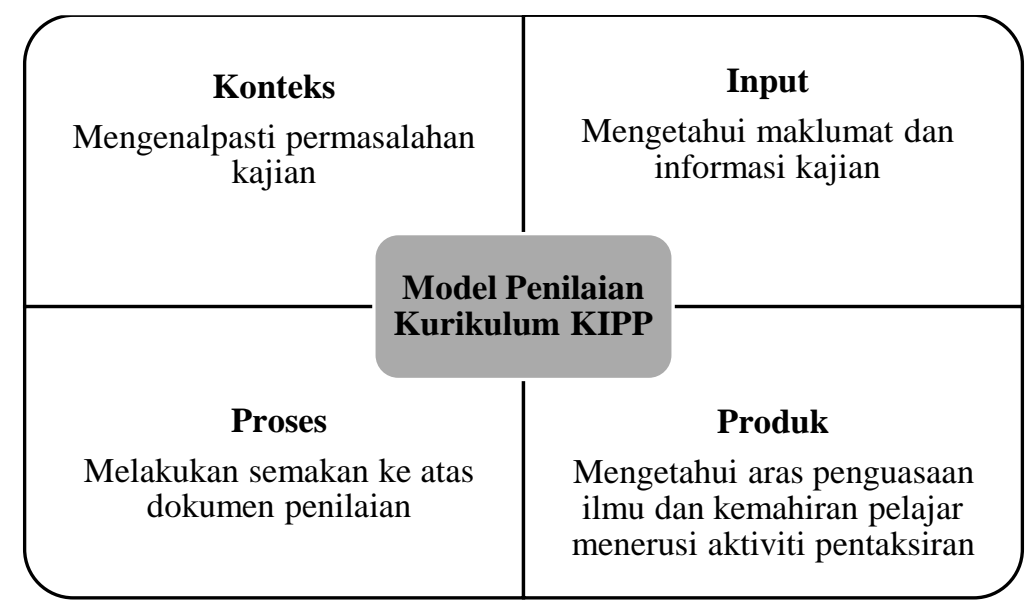

Rajah 2: Aplikasi komponen Model Penilaian KIPP di dalam kajian 


\section{Penilaian Konteks: Kekangan Masalah yang dihadapi dalam Proses Pentaksiran Berasaskan Produksi bagi Kursus Bangsawan}

Pada bahagian penilaian konteks, pengkaji mendapatkan maklum balas daripada persoalan kajian yang telah dikemukakan melalui pandangan dari dua jenis responden iaitu pengajar dan pelajar yang berkaitan dengan isu kekangan masalah yang dihadapi dalam proses pentaksiran berasaskan produksi. Kaedah yang digunakan dalam mengumpul maklumat ini adalah dengan cara mengadakan beberapa sesi temu bual dan pemerhatian yang dilakukan sepanjang proses pentaksiran dilaksanakan. Terdapat isu yang berbeza di antara pengajar dan pelajar di dalam mengenal pasti masalah yang timbul. Isu tersebut dinyatakan melalui Jadual 3 berikut:

Jadual 3: Senarai pendapat pengajar mengenai kekangan masalah pentaksiran kursus Bangsawan

\begin{tabular}{cl}
\hline Bil. & Kekangan masalah pentaksiran kursus Bangsawan \\
\hline 1. & Kesukaran dalam menentukan jawatan kerja produksi dalam Bangsawan. \\
\hline 2. & Komitmen pelajar dalam pentaksiran produksi Bangsawan. \\
\hline 3. & Kriteria pemarkahan dalam produksi Bangsawan. \\
\hline
\end{tabular}

Oleh itu, semakan di peringkat penilaian konteks Model Penilaian KIPP, responden pelajar dan pengajar menyatakan bahawa tidak ada garis panduan yang jelas tentang bagaimana untuk mengukur prestasi pelajar di dalam kerja produksi terutama yang memegang dua jawatan kerja iaitu jawatan kerja utama dan jawatan kerja tambahan. Dalam hal ini, berapakah markah keseluruhan yang dicapai menerusi gabungan markah jawatan kerja utama dan tambahan dan bagaimana untuk berlaku adil di dalam konteks pemberatan jawatan kerja produksi. Perkara ini disokong oleh kenyataan Nurfirdawati Muhamad Hanafi (2016) bahawa kriteriakriteria penilaian yang terlalu umum dan tidak mengandungi penerangan tingkah laku yang diharapkan dalam pembelajaran boleh menjadikan proses penilaian berdasarkan gerak hati, seterusnya berkemungkinan menjadikan pensyarah mula mencipta kriteria yang berbeza-beza di antara satu sama lain. Situasi ini boleh menyumbang kepada kesalahan dalam pengukuran dengan menjadikan maklum balas yang diberikan kepada pelajar tidak dapat menyatakan keputusan yang sah dan boleh dipercayai. Sehubungan dengan itu juga kecenderungan untuk berlaku bias dalam pentaksiran agak tinggi yang boleh mengganggu keputusan yang dibuat terhadap seseorang pelajar.

\section{Penilaian Input: Data Aktiviti Pentaksiran yang digunakan di dalam Kursus Produksi Bangsawan}

Penilaian input pula tertumpu kepada perancangan, strategi, prosedur dan sumber yang terlibat dalam membantu pencapaian matlamat dan objektif program. Oleh itu di dalam kajian ini, bahagian Input merupakan peringkat penilaian kedua dalam meneliti amalan pentaksiran berasaskan produksi kursus Bangsawan. Dapatan data ini diperjelaskan melalui hasil pemerhatian terhadap kaedah pentaksiran dalam produksi kursus Bangsawan yang dipraktikkan di Akademi Seni. Terdapat tiga peringkat utama dalam melaksanakan proses pentaksiran ini iaitu praproduksi, produksi dan pascaproduksi. Peringkat praproduksi ini ianya merujuk kepada prosedur penilaian pelajar berpandukan Pentaksiran Proses Produksi (PPP) dan Persembahan Pertengahan Semester (PPS). Sebanyak 70\% markah diperuntukkan kepada pelajar dalam pentaksiran yang melibatkan latihan amali tentang pembelajaran Adat Istiadat Bangsawan. Latihan amali Adat Istiadat merupakan salah satu daripada 10 aktiviti pengajaran di dalam kursus Bangsawan yang dapat dinyatakan pada Jadual 4 seperti berikut:

Jadual 4: Latihan Amali Produksi Bangsawan

\begin{tabular}{cl}
\hline Bil. & Latihan Amali \\
\hline 1. & Pergerakan \\
\hline 2. & Adat Istiadat \\
\hline 3. & Lakonan \\
\hline 4. & Asas Gerak Pentas \\
\hline 5. & Pemilihan Cerita \\
\hline 6. & Rekaan Pentas \\
\hline 7. & Muzik \\
\hline
\end{tabular}




\begin{tabular}{cl}
\hline Bil. & Latihan Amali \\
\hline 8. & Kostum \\
\hline 9. & Tatarias \\
\hline 10. & Tasmat \\
\hline
\end{tabular}

Lanjutan itu, di peringkat ini juga, terdapat tiga sesi pembentangan mengenai pengurusan produksi dengan tujuan untuk menilai prestasi pelajar berdasarkan bidang kerja yang diberi seperti Jadual 5.

Jadual 5: Sesi perbentangan produksi Bangsawan

\begin{tabular}{ccc}
\hline Sesi 1 & Sesi 2 & Sesi 3 \\
\hline $\begin{array}{c}\text { Idea cerita dan naskhah } \\
\text { Bangsawan }\end{array}$ & Idea dan konsep rekaan produksi & $\begin{array}{c}\text { Cadangan pembuatan dan } \\
\text { perlaksanaan }\end{array}$ \\
\hline Semua unit terlibat & Unit terlibat & \\
\hline & Pengurusan produksi & Pengurusan produksi \\
& Rekaan set dan prop & Rekaan set dan prop \\
& Kostum dan solekan & Kostum dan solekan \\
& Komposisi muzik & Komposisi muzik \\
& Rekaan grafik dan multimedia & Rekaan grafik dan multimedia \\
Rekaan cahaya & Rekaan cahaya \\
Rekaan bunyi & Rekaan bunyi \\
\hline
\end{tabular}

Terdapat tiga peringkat pembentangan yang perlu dilaksanakan oleh pelajar di peringkat praproduksi iaitu pembentangan sesi 1 , sesi 2 dan sesi 3 . Pada sesi 1, pembentangan ini melibatkan idea cerita dan naskhah Bangsawan yang mana proses pemilihan cerita dibuat dan pecahan babak atau breakdown script akan dihasilkan. Manakala sesi 2, idea dan konsep rekaan produksi dibentangkan bagi mengetahui lakaran ilustrasi bagi setiap unit kreatif berserta kajian visual untuk diaplikasikan ke dalam produksi Bangsawan. Dan akhir sekali adalah cadangan pembuatan dan perlaksanaan. Pembentangan ini adalah penting bagi mengetahui setiap rekaan dapat direalisasikan dengan secara realistik berdasarkan proses rekaan produksi. Dalam hal ini perlaksanaan rekaan menyentuh kepada penyediaan bahan mentah, durasi masa pembikinan, scoring muzik, proses bump in dan bump out. Justeru itu, pentaksiran prestasi diterapkan oleh pengajar bagi mengenal pasti kefahaman pelajar untuk melaksanakan tugas dan tanggungjawab dalam produksi Bangsawan. Berdasarkan kenyataan David Payne (2003) dalam bukunya Applied Educational Assessment Edisi ke-2, pentaksiran ialah integrasi proses mengumpul maklumat, menginterpretasikan maklumat atau memberi nilai kepada maklumat itu dan membuat keputusan berdasarkan interpretasi yang dibuat ke atas maklumat. Oleh itu input ini dikumpul bagi melihatkan perkembangan pembelajaran pelajar dengan secara holistik.

Sehubungan itu, penilaian input tentang aktiviti pentaksiran PPS ini dilaksanakan selama tiga jam dengan melihat aturan yang berkaitan dengan senarai perjalanan Persembahan Pertengahan Semester (PPS) yang dapat dinyatakan seperti Jadual 6 berikut:

Jadual 6: Aturan aktiviti Persembahan Pertengahan Semester (PPS) produksi Bangsawan Badang

\begin{tabular}{cl}
\hline Bil. & Perkara \\
\hline 1. & $\begin{array}{l}\text { Taklimat pengajar kursus Bangsawan berkaitan dengan aktiviti Persembahan Pertengahan } \\
\text { Semester (PPS) }\end{array}$ \\
\hline 2. & $\begin{array}{l}\text { Arahan Pengurus Pentas berkaitan babak persembahan dan juga peringatan tentang kawalan } \\
\text { perjalanan bagi setiap unit produksi }\end{array}$ \\
\hline 3. & Lagu Overture Bangsawan \\
\hline 4. & Gurindam \\
\hline 5. & Selingan Extra Turn \\
\hline 6. & Babak Balairung Seri \\
\hline 7. & Selingan Extra Turn \\
\hline 8. & Babak Kampung / Desa \\
\hline 9. & Selingan Extra Turn \\
\hline 10. & Babak Hutan \\
\hline 11. & Selingan Extra Turn \\
\hline
\end{tabular}




\begin{tabular}{ll}
\hline Bil. & Perkara \\
\hline 12. & Babak Taman Istana \\
\hline 13. & Selingan Extra Turn \\
\hline 14. & Babak Hutan \\
\hline 15. & Selingan Extra Turn \\
\hline 16. & Babak Taman Istana \\
\hline 17. & Selingan Extra Turn \\
\hline 18. & Babak Kampung / Desa \\
\hline 19. & Lagu Penutup Bangsawan \\
\hline 20. & Taklimat pengajar berkaitan perjalanan pentaksiran atau pemurnian produksi \\
\hline
\end{tabular}

\section{Input Kriteria Pemarkahan Produksi Bangsawan Badang}

Menerusi semakan terhadap dokumen pentaksiran yang digunakan oleh pengajar kursus produksi Bangsawan, terdapat empat sumber utama di dalam kriteria pemarkahan iaitu lakon, tari, muzik dan pengurusan produksi.

\section{Kriteria Pemarkahan Pelakon}

Bidang penilaian bagi pelakon dinamakan sebagai lakon, manakala komponen utama lakon adalah lakonan. Oleh yang demikian, penilaian komponen lakonan dibahagikan kepada empat kriteria yang digunakan sebagai alat pengukur dalam menentukan aras atau tahap prestasi pelajar iaitu watak-perwatakan, vokal, penguasaan ruang dan hafalan.

\section{Kriteria Pemarkahan Koreografer dan Penari}

Terdapat tiga pecahan utama di dalam kriteria pemarkahan bagi koreografer dan penari. Pecahan tersebut merujuk kepada bidang, komponen dan kriteria. Justeru itu, bidang penilaian bagi koreografer dan penari dinamakan sebagai tari, manakala komponen utamanya terbahagi kepada dua iaitu koreografi dan tarian. Merujuk kepada komponen koreografi, terdapat empat kriteria penilaian iaitu kreativiti, keaslian gerak, koordinasi muzik dan gerakan serta pola lantai. Manakala komponen tarian diukur berdasarkan lima kriteria iaitu kualiti persembahan, disiplin dalam persembahan, tanggungjawab berkumpulan, hafalan dan akhir sekali adalah busana dan tatarias.

\section{Kriteria Pemarkahan Pengarah Muzik dan Pemuzik}

Bidang muzik mempunyai dua komponen utama dalam penilaian iaitu gubahan dan ciptaan muzik yang mewakili kriteria pengarah muzik manakala muzik adalah komponen yang mewakili kriteria Pemuzik. Justeru itu, komponen gubahan dan ciptaan muzik diukur berdasarkan empat kriteria penilaian iaitu idea dan kreativiti, keaslian gubahan, hasil, impak dan interpretasi serta kepimpinan. Komponen muzik pula dijelaskan berdasarkan empat kriteria iaitu kualiti persembahan, disiplin dalam persembahan, tanggungjawab berkumpulan dan hafalan.

\section{Kriteria Pemarkahan Pengurusan Produksi dan Pereka}

Kriteria pemarkahan pengurusan produksi dapat dijelaskan sebagai penilaian terhadap bidang pengurusan dan pereka produksi yang mana terdiri daripada dua komponen yang mewakili jawatan kerja dalam produksi. Komponen 1, menjurus kepada kerja pengurus produksi, penolong pengurus produksi, pengarah teknikal, pengarah promosi \& publisiti, pengurus pentas dan penolong pengurus pentas. Manakala komponen 2, mewakili jawatan kerja pereka set \& prop, pereka multimedia, pereka kostum, pereka tatarias dan unit front of house (F.O.H). Justeru itu, pengkaji menggunakan komponen 1 dan 2 dalam menjelaskan kriteria penilaian yang dipraktikkan di dalam pentaksiran ini. Bagi komponen 1, terdapat empat kriteria utama dalam mengukur keupayaan pelajar iaitu kepimpinan, kecekapan dan kepantasan, tanggungjawab 
kerja berpasukan dan komunikasi lisan dan bertulis. Manakala komponen 2, terdapat empat kriteria penting dalam penilaian iaitu idea, inovasi dan kreativiti, hasil dan impak, tanggungjawab kerja berpasukan, komitmen dan disiplin dan komunikasi lisan dan bertulis.

\section{Penilaian Proses: Analisis Rubrik Produksi Bangsawan Berdasarkan Kriteria Metarubrik}

Berdasarkan kajian ini, penilaian proses melihat kepada perlaksanaan pentaksiran dalam menentukan markah atau gred bagi seorang pelajar. Berdasarkan penilaian proses ini, setiap responden diberikan dokumen rubrik produksi Bangsawan berserta jadual semakan Metarubrik adaptasi dari Scoring Rubrics in The Classroom oleh Arter \& McTighe (2001) untuk menentukan kesahan dan kebolehpercayaan pentaksiran yang dilakukan.

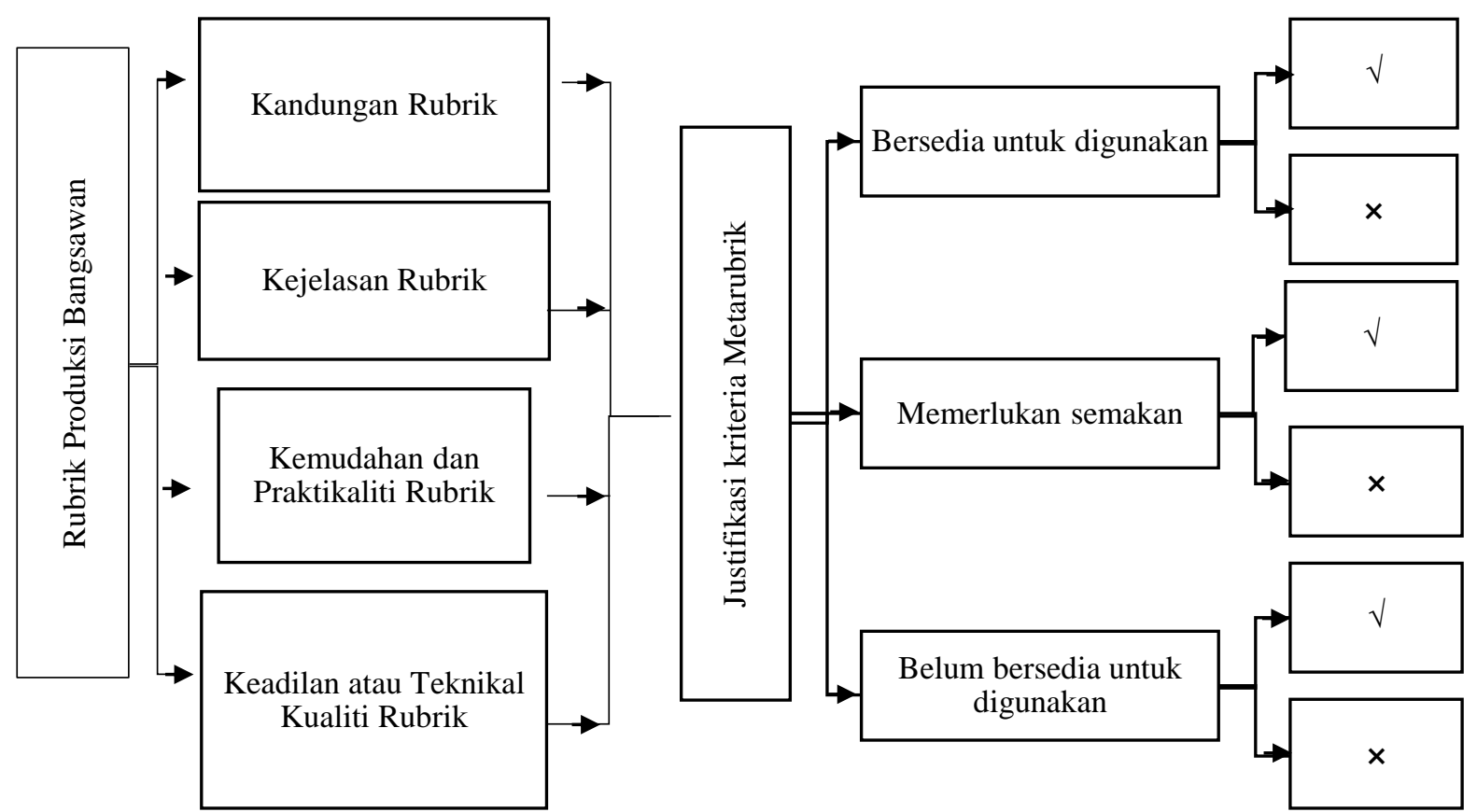

Rajah 3: Prosedur Proses Semakan Rubrik Produksi Bangsawan dengan menggunakan Kriteria Metarubrik.

Di peringkat penilaian proses, kriteria rubrik Bangsawan dinilai dan disemak oleh lima orang pakar bidang dengan berpandukan jadual kriteria Metarubrik menerusi Scoring Rubrics in the Classroom oleh Arter \& McTighe (2001). Oleh yang demikian, hasil dapatan kajian di peringkat proses Model Penilaian KIPP dapat dinyatakan mengikut kandungan rubrik, kejelasan rubrik, kemudahan dan Praktikaliti Rubrik dan Keadilan atau Teknikal Kualiti Rubrik.

\section{Kandungan Rubrik}

Menerusi dapatan kajian berkaitan kandungan rubrik ini, Responden Pakar Bidang menyatakan bahawa terdapat beberapa justifikasi yang perlu disemak semula terutama dari segi selektif, releven dan kelengkapan kandungan. Nurfirdawati Muhamad Hanafi (2016) menjelaskan bahawa ketiadaan kriteria yang standard atau kriteria terlalu umum juga kemungkinan dapat mewujudkan percanggahan penekanan terhadap kriteria penilaian yang digunakan oleh kebanyakan pensyarah baru. Arter \& McTighe (2001) menerangkan bahawa kandungan rubrik merupakan definisi bagi kandungan standard kerana rubrik menjelaskan tentang apakah yang akan dikira berdasarkan kepada apa yang dinyatakan dalam kandungan standard, kerangka kurikulum, atau bahan pengajaran, kandungan rubrik adalah apa yang pensyarah dan pelajar akan gunakan untuk menentukan apa yang mereka perlu buat untuk berjaya. Oleh itu adalah satu kemestian bahawa rubrik perlu merangkumi semua aspek-aspek asas yang menentukan kualiti sesuatu produk atau prestasi. Dalam hal ini, perkara yang perlu disemak adalah berkaitan dengan kriteria vokal, hafalan, watak perwatakan, hasil, impak dan interpretasi serta kepimpinan. Bagi penilaian vokal, penyediaan rubrik perlu menjelaskan secara 
lengkap tentang penggunaan vokal di dalam Bangsawan dan bukan vokal untuk lakonan semata-mata. Hasil dapatan ini disokong oleh Abdul Samad Salleh (2003) iaitu untuk menjayakan tugas vokal ini, kepetahan mengeluarkan kata-kata secara sepontan adalah penting. Pelakon harus cepat bertindak untuk mengeluarkan kata-kata yang bertepatan dengan adegan, babak atau cerita pada saat-saat tersebut. Kebetulan pula dialogdialog bangsawan bukanlah kata-kata harian atau dialog biasa tetapi bahasa-bahasa istana yang berpuisi. Kecepatan berfikir, kepetahan berkata dan menyusun kata dapat memadatkan rangka senario yang tersedia. Begitujuga dengan penilaian ke atas kriteria hafalan untuk bidang lakonan, muzik dan tarian yang mana kelihatan tidak selektif untuk menjelaskan tentang perkara yang ingin diuji melalui bidang tersebut. Nadarajan Thambu (2014) menyatakan bahawa sesuatu yang dihafal akan tertanam secara konkrit dalam minda individu apabila mereka aktif secara jasmani dan terlibat secara emosi. Semasa berlakon seseorang pelakon perlu menyebutkan satu per satu dialog yang dihafal dan dialog ini secara langsung akan hidup dalam minda dan bertahan lama untuk satu jangka waktu yang panjang untuk membentuk tingkah laku. Dalam hal ini, responden pakar bidang ingin melihat perbezaan kriteria hafalan di antara bidang lakonan, muzik dan tarian. Manakala dapatan kajian bagi kandungan kriteria watak perwatakan dilihat terlalu umum dan sukar untuk membezakan penilaian ke atas pelbagai jenis watak seperti watak utama, watak pembantu dan watak sampingan. Rosman Ishak (2014) menyatakan bahawa bentuk watak perwatakan yang terdapat dalam persembahan Bangsawan lebih merujuk kepada watak-watak tetap (stock character) yang terdiri daripada pelbagai hierarki dalam masyarakat iaitu wirawati, wira, menteri, orang pertapaan, hulubalang, dayang-dayang, orang kampong, raja-raja jin dan ahli lawak. Dalam hal ini, kandungan kriteria bagi watak perwatakan perlu disemak semula kerana justifikasi kriteria tersebut perlu dinilai berdasarkan kepada pergerakan, lenggok, emosi, tarik nasib dan pengucapan watak perwatakan di dalam Bangsawan. Seterusnya, kriteria hasil, impak dan interpretasi adalah sesuatu kriteria yang meragukan kerana di dalam kriteria tersebut terdapat tiga perkara yang ingin diuji kepada pelajar iaitu; (1) hasil, (2) impak, dan (3) interpretasi. Dalam hal ini, kriteria tersebut tidak jelas untuk menilai sesuatu proses kerja di dalam produksi dan berpotensi untuk pengajar memberi markah berdasarkan pengamatan rasa. Perkara ini disokong oleh kenyataan Moskal (2003) bahawa kriteria yang dikemukakan dalam rubrik penskoran sepatutnya dijelaskan dalam istilah tingkah laku yang boleh dilihat atau karektor produk yang boleh diukur. Dan akhir sekali adalah berkaitan dengan kriteria kepimpinan. Dapatan kajian melihat justifikasi ini tidak lengkap kerana ianya tidak menjelaskan secara khusus tentang proses kepimpinan bagi setiap bidang seperti mengurus, memimpin, membahagi kerja, mengorganisasikan kerja dan sebagainya. Dalam konteks proses kepimpinan adalah merujuk kepada sebahagian dari pengurusan tetapi bukan keseluruhannya. Justeru, proses kepimpinan dalam konteks kajian ini adalah merujuk kepada keupayaan untuk mempengaruhi orang lain untuk mencapai objektif-objektif yang ditentukan, dengan bersemangat. Ia adalah faktor kemanusiaan yang mana mengikat satu kumpulan dan memotivasikan ke arah matlamat. Aktiviti-aktiviti pengurusan seperti perancangan, pengorganisasian dan membuat keputusan adalah sesuatu yang tidak aktif sehingga pemimpin mencetuskan kuasa motivasi ke dalam jiwa pengikutnya dan memandu mereka ke arah matlamat.

Dapatan kajian ini juga melihat kepada kandungan rubrik yang standard berdasarkan aktiviti pengajaran dan pembelajaran kursus produksi Bangsawan. Menurut Chapman \& King (2012) standard adalah tanda aras atau kemahiran khusus yang dikenal pasti untuk dikuasai dalam bidang tertentu untuk tahap dan gred yang khusus. Dalam hal ini, terdapat 10 aktiviti pengajaran bagi kursus produksi Bangsawan iaitu pergerakan, adat istiadat, lakonan, asas gerak pentas, pemilihan cerita, rekaan pentas, muzik, kostum, tatarias dan Tasmat. Justeru itu, 10 aktiviti tersebut dijadikan landasan utama di dalam amalan pentaksiran berasaskan produksi bagi kursus Bangsawan yang melalui tiga peringkat penilaian iaitu praproduksi, produksi dan pascaproduksi. Selain itu juga, kandungan rubrik ini dapat menggambarkan tahap pemikiran yang baik tentang perlaksanaan sesuatu produk atau pertimbangan ke atas penguasaan kemahiran. Dapatan kajian menemui beberapa penggunaan perkataan seperti 'berkebolehan,' berketerampilan,' 'bertanggungjawab' dan sebagainya dapat mengukur aras penguasaan kemahiran yang dilihat menerusi domain taksonomi bloom iaitu kognitif, afektif dan psikomotor. Mengikut Arter \& McTighe (2001) menjelaskan bahawa rubrik yang direka bentuk dengan baik dapat membantu pensyarah untuk menentukan sasaran pembelajaran. Oleh itu, ia akan dapat merancang pengajaran lebih efektif, lebih konsisten dalam memberikan skor terhadap hasil kerja pelajar, dan lebih sistematik dalam melaporkan kemajuan pelajar. Ini adalah kerana apabila pelajar mengetahui kriteria-kriteria kualiti untuk meningkatkan prestasi, mereka akan menyediakan matlamat yang jelas untuk melaksanakan kerja yang diberikan. 


\section{Kejelasan Rubrik}

Perbincangan berkaitan semakan terhadap kejelasan rubrik adalah berpandukan kepada penggunaan perkataan yang spesifik dan tepat dengan maksud penilaian. Oleh yang demikian, hasil daripada semakan ke atas rubrik produksi Bangsawan, terdapat beberapa penggunaan perkataan yang tidak spesifik dan kurang jelas hingga menimbulkan pemahaman yang berlainan daripada maksud sebenar kriteria. Melalui pandangan Arter \& McTighe (2001) bahawa penggunaan perkataan yang tidak jelas mengakibatkan maksud di dalam penilaian terganggu dan interpretasi juga pelbagai. Dalam hal ini, kejelasan rubrik perlu standard dari segi pemahaman yang digunakan oleh penilai. Seperti kriteria 'kualiti persembahan' yang terdapat di dalam bidang tari, ianya tidak menggunakan perkataan yang spesifik bagi menggambarkan situasi kualiti tarian itu sendiri yang mana sepatutnya di dalam indikator rubrik tersebut, menggunakan perkataan ketepatan irama, ketepatan gerak, lenggok dan penjiwaan terhadap muzik dan gerak. Moskal (2003) menegaskan rubrik penskoran sepatutnya ditulis dalam spesifik dan bahasa yang jelas untuk pelajar faham. Hal ini berkait rapat dengan perkataan 'disiplin' dalam bidang tari yang sepatutnya dengan spesifik menggunakan perkataan 'keseragaman' dan 'ekspresi yang setara dengan mood tarian.' Terdapat juga penggunaan ayat di dalam indikator yang tidak tepat untuk memperjelaskan kriteria 'kepimpinan' di dalam bidang pengurusan produksi, tarian dan muzik. Indikator tersebut adalah 'mempunyai kebolehan hanya memenuhi kehendak pensyarah dengan melakukan sedikit kesalahan dan kesilapan yang berpatutan.' Dalam hal ini, penggunaan ayat tersebut terlalu panjang dan mengelirukan kerana ianya tidak menggambarkan ciri-ciri kepimpinan yang tepat. Perkara ini disokong oleh Rusmawati Othman \& Mohd. Isha Awang (2018) melalui kajian pentaksiran yang mana perincian item menunjukkan wujud masalah dalam menggunakan rubrik. Antara yang dikesan dalam dapatan adalah kesulitan menaksir kriteria untuk pemberian markah pada satu julat markah kerana ayat pada rubrik terlalu panjang. Frederiksen \& Collins (1989) menyatakan juga tentang penggunaan istilah transparency untuk menyatakan idea bahawa pelajar perlu mendapatkan pemahaman yang jelas tentang kriteria yang terlibat dengan penilaian hasil kerja mereka. Sehubungan dengan itu, penilaian hasil kerja pelajar sepatutnya telus dan transparency supaya pelajar dapat menilai kerja mereka sama ada selari dengan kehendak pensyarah.

Kejelasan rubrik juga dilihat berdasarkan penentuan rating di dalam rubrik produksi Bangsawan. Hasil dapatan kajian yang telah dilakukan, rubrik produksi Bangsawan menggunakan lima rating yang membezakan di antara tahap sangat lemah, lemah, sederhana, baik dan sangat baik. Menurut McMillan (2000) mengatakan bahawa rubrik ialah hasil gabungan di antara kriteria penskoran dengan skala pemeringkatan (rating scale) yang merupakan asas kepada panduan penskoran secara menyeluruh. Begitu juga dengan Gazdik (2009) yang mendefinisikan rubrik penskoran sebagai skema penskoran deskriptif yang menyenaraikan kriteria yang diperlukan dalam sesuatu tugasan dan menyediakan maklumat tentang apa yang mesti dimasukkan untuk mendapatkan tahap-tahap yang tertentu dalam sesuatu pencapaian. Namun begitu, terdapat kelemahan dari segi jumlah markah bagi setiap rating yang berbeza-beza di antara satu bidang dengan bidang yang lain. Keadaan ini menyebabkan ketidakseimbangan di dalam pentaksiran yang boleh menjejaskan himpunan markah akhir pelajar di dalam produksi Bangsawan. Melalui Garis Panduan Amalan Baik: Penilaian Pelajar MQA (2014) kebolehpercayaan merangkumi konsistensi dalam penilaian dan pengredan. Ia mencerminkan sejauh mana penanda oleh pemeriksa adalah tepat, konsisten, boleh dipercayai, adil dan boleh diterima. Ini boleh dipastikan dengan mudah melalui pematuhan terhadap skema jawapan atau rubrik. Oleh yang demikian menyediakan skema pemarkahan atau rubrik sebagai panduan untuk memastikan keseragaman semasa menanda. Kriteria pemarkahan yang kabur mengancam kebolehpercayaan.

\section{Kemudahan dan Praktikaliti Rubrik}

Perbincangan bagi kriteria ini, tertumpu kepada rubrik yang mudah dan senang untuk diuruskan. Tegas Arter \& McTighe (2001) bahawa trait bagi kebolehgunaan adalah merujuk kepada 'mudah untuk digunakan.' Sebagai contoh bolehkah seseorang pensyarah dan pelajar memahami dan menggunakan rubrik dengan mudah? Adakah rubrik memberikan maklumat yang diperlukan oleh pensyarah dan pelajar untuk membuat keputusan dalam pengajaran dan mengesan kemajuan pelajar ke arah hasil pembelajaran yang penting? Bolehkah rubrik digunakan untuk menaksir pelajar sahaja? Adakah rubrik juga boleh digunakan untuk memperbaiki pencapaian yang ditaksirkan? Oleh yang demikian hasil kajian mendapati bahawa rubrik produksi Bangsawan adalah salah satu kaedah yang baik dalam menilai kemampuan pelajar menerusi tugasan, prestasi dan portfolio. Namun begitu, responden pakar bidang menyatakan bahawa rubrik yang 
disediakan ini perlu lebih mengkhusus kepada prosedur kerja di dalam produksi yang mana dapat melatih keupayaan kemahiran insaniah pelajar. Melalui Stiggins (2006) menyatakan bahawa pelajar merupakan kunci utama pengguna pentaksiran dan sepatutnya guru boleh menggunakan pentaksiran dalam pelbagai cara untuk menentukan standard kualiti prestasi, dan untuk memberikan panduan atau bimbingan maklum balas secara berterusan mengenai kemajuan pembelajaran pelajar ke arah penggunaan standard tersebut.

\section{Keadilan dan Kualiti Teknikal Rubrik}

Hasil dapatan kajian menjelaskan bahawa rubrik produksi Bangsawan ini telah memenuhi keperluan asas di dalam penyediaan rubrik seperti baris kolum rating, tajuk kriteria, justifikasi dan tajuk bidang. Jelas Arter \& McTighe (2001) menyatakan kesempurnaan teknikal adalah berkaitan dengan maklumat-maklumat teknikal yang terdapat di dalam rubrik yang menyatakan kadar persetujuan pemeriksa dan keadaan-keadaan yang mana kadar persetujuan boleh diperoleh. Namun begitu, semakan perlu dilakukan ke atas pembahagian skala peratusan yang diperuntukkan bagi setiap bidang. Dalam hal ini, pakar bidang mendapati wujud ketidakadilan di dalam meletakkan markah peratus bagi setiap bidang. Justeru itu, cadangan responden pakar bidang adalah untuk melihat setiap pelajar dinilai berdasarkan markah peratusan yang sama walaupun bidang yang berbeza-beza. Moskal (2003) bilangan mata yang digunakan dalam rubrik penskoran sepatutnya memberikan kesan. Nilai mata yang ditentukan sama ada untuk analitik atau holistik rubrik penskoran sepatutnya dapat menunjukkan nilai aktiviti dengan jelas. Begitu juga dengan bilangan kriteria bagi setiap bidang, terdapat ketidaksamaan bilangan kriteria di antara satu bidang dengan bidang yang lain. Dalam hal ini, dicadangkan supaya bilangan kriteria bagi setiap bidang adalah sama di antara lima atau empat kriteria sahaja. Nurfirdawati Muhamad Hanafi (2016) pensyarah juga perlu memahami ciri-ciri kualiti rubrik. Sekiranya rubrik tidak mengandungi ciri-ciri kualiti kerja yang betul-betul boleh mengukur dan menentukan kualiti kerja, pensyarah akan mengajar sasaran pembelajaran yang salah dan pelajar akan belajar sasaran pembelajaran yang salah juga. Oleh yang demikian, Nurfirdawati Muhamad Hanafi (2016) menyata lagi bahawa terdapat prosedur yang dapat meminimumkan kesalahan dalam penskoran iaitu; (1) berhati-hati semasa membina kriteria, tugasan, dan penskoran rubrik, (2) mempunyai penskoran rubrik yang sistematik, dan (3) menggunakan lebih daripada seorang pemeriksa.

\section{Penilaian Produk: Analisis Hasil Amalan Pentaksiran bagi Kursus Produksi Bangsawan Berdasarkan Aras Taksonomi Bloom}

Penilaian produk tertumpu kepada hasil amalan pentaksiran bagi kursus produksi Bangsawan. Penilaian tersebut melihat kepada matlamat dan objektif bagi setiap peringkat pentaksiran yang ingin dicapai pada akhir kursus. Selain itu juga, hasil amalan pentaksiran produksi Bangsawan ini dijelaskan menerusi Teori Taksonomi Bloom, yang mana terdapat tiga objektif pengajaran yang dianalisis iaitu Domain Kognitif; kemahiran mental (Pengetahuan), Domain Afektif; perkembangan perasaan atau emosi (Sikap) dan Domain Psikomotor; kemahiran fizikal (Kemahiran). Oleh yang demikian, penilaian produk ini melihat kepada tahap penguasaan mental, emosi serta kemahiran bagi menentukan aras kesukaran pelajar bagi setiap peringkat pentaksiran iaitu praproduksi, produksi dan pascaproduksi.

Jadual 7: Peringkat pentaksiran produksi Bangsawan berpandukan penguasaan Domain Taksonomi Bloom.

\begin{tabular}{|c|c|c|c|c|c|}
\hline \multirow[t]{2}{*}{$\begin{array}{c}\text { Peringkat } \\
\text { pentaksiran }\end{array}$} & \multirow[t]{2}{*}{$\begin{array}{c}\text { Objektif Peringkat } \\
\text { Pentaksiran }\end{array}$} & \multirow[t]{2}{*}{ Aktiviti Pentaksiran } & \multicolumn{3}{|c|}{$\begin{array}{c}\text { Domain Taksonomi } \\
\text { Bloom }\end{array}$} \\
\hline & & & 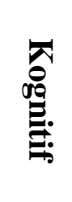 & 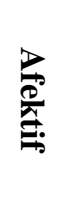 & 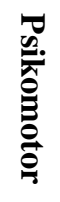 \\
\hline \multirow{3}{*}{$\begin{array}{l}\text { Praproduksi } \\
\text { Bangsawan }\end{array}$} & \multirow{3}{*}{$\begin{array}{c}\text { Merancang proses kerja } \\
\text { dalam produksi } \\
\text { Bangsawan }\end{array}$} & - Pergerakan & & $\sqrt{ }$ & $\sqrt{ }$ \\
\hline & & - Adat Istiadat & & $\sqrt{ }$ & $\sqrt{ }$ \\
\hline & & - Lakonan & & $\sqrt{ }$ & $\sqrt{ }$ \\
\hline
\end{tabular}




\begin{tabular}{|c|c|c|c|c|c|}
\hline \multirow[t]{9}{*}{$\begin{array}{c}\text { Peringkat } \\
\text { pentaksiran }\end{array}$} & \multirow[t]{9}{*}{$\begin{array}{c}\text { Objektif Peringkat } \\
\text { Pentaksiran }\end{array}$} & \multirow[t]{2}{*}{ Aktiviti Pentaksiran } & \multicolumn{3}{|c|}{$\begin{array}{c}\text { Domain Taksonom } \\
\text { Bloom }\end{array}$} \\
\hline & & & 중. & 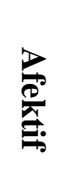 & 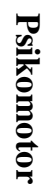 \\
\hline & & - Asas Gerak Pentas & & & $\sqrt{ }$ \\
\hline & & - Pemilihan Cerita & $\sqrt{ }$ & & \\
\hline & & - Rekaan Pentas & $\sqrt{ }$ & & $\sqrt{ }$ \\
\hline & & - Muzik & $\sqrt{ }$ & $\sqrt{ }$ & $\sqrt{ }$ \\
\hline & & - Kostum & $\sqrt{ }$ & & $\sqrt{ }$ \\
\hline & & - Tatarias & $\sqrt{ }$ & & $\sqrt{ }$ \\
\hline & & - Tasmat & $\sqrt{ }$ & & $\sqrt{ }$ \\
\hline \multirow[t]{4}{*}{$\begin{array}{c}\text { Produksi } \\
\text { Bangsawan }\end{array}$} & \multirow[t]{4}{*}{$\begin{array}{c}\text { Melaksanakan } \\
\text { persembahan di dalam } \\
\text { produksi Bangsawan }\end{array}$} & 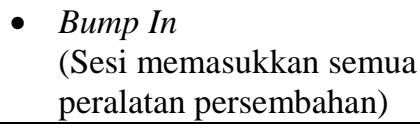 & & & $\sqrt{ }$ \\
\hline & & $\begin{array}{l}\text { Set up } \\
\text { (Tirai bangsawan, set, } \\
\text { kostum, solekan, cahaya, } \\
\text { bunyi, muzik, pameran } \\
\text { dan multimedia) }\end{array}$ & & & $\sqrt{ }$ \\
\hline & & - Pementasan bangsawan & & $\sqrt{ }$ & $\sqrt{ }$ \\
\hline & & $\begin{array}{l}\text { Bump Out } \\
\text { (Sesi mengemas semua } \\
\text { peralatan persembahan) } \\
\end{array}$ & & & $\sqrt{ }$ \\
\hline $\begin{array}{l}\text { Pascaproduksi } \\
\text { Bangsawan }\end{array}$ & $\begin{array}{c}\text { Mendokumentasikan hasil } \\
\text { kerja produksi berdasarkan } \\
\text { bidang tugas }\end{array}$ & - Laporan produksi & $\sqrt{ }$ & & \\
\hline
\end{tabular}

Model Penilaian KIPP di peringkat produk mendapati bahawa aktiviti pentaksiran menerusi peringkat penilaian praproduksi, produksi dan pascaproduksi telah memenuhi keperluan hasil pembelajaran kursus iaitu mendalami struktur dan komponen Bangsawan dengan lebih jelas, melatih pelajar dengan mengerjakan sesebuah produksi dan memperkukuhkan jati diri pelajar dalam memahami kesenian tradisional Malaysia. Berdasarkan pada Garis Panduan Amalan Baik: Penilaian Pelajar oleh MQA (2014) Pelbagai kaedah penilaian perlu diguna pakai dalam mengukur pencapaian hasil pembelajaran yang merangkumi pelbagai atribut yang hendak diukur. Pemilihan tugas penilaian dibuat berdasarkan amalan biasa dalam disiplin masing-masing mengikut pengalaman seseorang. Pemilihan instrumen mesti ditentukan berdasarkan kriteria penilaian, dari segi kualiti dan kebolehan yang diingini daripada pelajar seperti yang dinyatakan dengan jelas di dalam penyataan hasil pembelajaran atau learning outcomes. Begitu juga dengan tahap penguasaan pelajar di dalam pentaksiran berdasarkan domain Taksonomi Bloom. Dapatan kajian mendapati bahawa aktiviti pentaksiran ini mempunyai tahap penguasaan pembelajaran yang seimbang dari segi domain kognitif, afektif dan psikomotor. Howard (2007) menyatakan bahawa penggunaan taksonomi dalam pendidikan banyak digunakan terhadap penetapan objektif dalam sesuatu kurikulum dan penilaian. Sehubungan itu, kerja amali atau hands-on adalah perkara utama bagi mentransformasikan pengetahuan kognitif mereka melalui aplikasi psikomotor. Dalam hal ini, bidang kerja praktikal di dalam produksi adalah penting untuk persediaan pelajar bagi mempraktikkan dan menguasai sesuatu prosedur kerja yang jelas dan betul untuk memenuhi keperluan apabila menghadapi pekerjaan sebenar.

Dapatan kajian dan analisis ini dapat disimpulkan bahawa amalan pentaksiran berasaskan produksi bagi kursus Bangsawan mempunyai kaedah penilaian yang jelas dengan menetapkan pembahagian pentaksiran kepada tiga peringkat iaitu praproduksi, produksi dan pascaproduksi. Kaedah tersebut telah memperincikan setiap aktiviti pentaksiran yang perlu dilaksanakan oleh pelajar kursus Bangsawan semasa 
perancangan produksi, perlaksanaan produksi dan pemurnian produksi. Berdasarkan Model Penilaian KIPP, setiap aktiviti di dalam pentaksiran berasaskan produksi ini dianalisis dengan berpandukan komponen penilaian iaitu konteks, input, proses dan produk. Secara berperingkat setiap komponen di dalam Model Penilaian KIPP diselidiki bagi membantu dalam memperjelaskan isu dan permasalahan di dalam topik kajian ini. Komponen pertama iaitu penilaian konteks telah menemui tiga informasi penting yang berkaitan dengan isu pentaksiran iaitu kesukaran dalam menentukan jawatan kerja produksi dalam Bangsawan, komitmen pelajar dalam pentaksiran produksi Bangsawan dan kriteria pemarkahan dalam produksi Bangsawan. Seterusnya komponen kedua iaitu penilaian input telah menjelaskan maklumat peringkat penilaian terhadap aktiviti pentaksiran praproduksi, produksi dan pascaproduksi. Di samping itu juga maklumat berkaitan rubrik produksi Bangsawan dikumpul bagi mengetahui kriteria yang terkandung di dalam fokus penilaian. Manakala komponen ketiga iaitu penilaian proses tertumpu kepada semakan rubrik produksi Bangsawan yang dianalisis bersama kriteria Metarubrik oleh lima pakar bidang yang dipilih sebagai responden kajian. Hasil dari maklum balas dari lima pakar bidang mendapati bahawa rubrik produksi Bangsawan mempunyai ketidakseimbangan dalam penilaian dan perlu disemak semula. Di samping itu, pakar bidang ini turut menegaskan bahawa setiap aktiviti pentaksiran di dalam kursus produksi Bangsawan memiliki aras penguasaan domain Taksonomi Bloom yang seimbang sama ada Kognitif, Afektif mahupun Psikomotor. Ringkasnya, hasil dari maklum balas dapatan menunjukkan amalan pentaksiran berasaskan produksi bagi kursus Bangsawan dapat mengenal pasti kelemahan pentaksiran melalui Model Penilaian KIPP secara menyeluruh dan holistik.

\section{Kesimpulan}

Berdasarkan Model Penilaian KIPP, terdapat beberapa hasil dapatan yang telah diperoleh untuk dibincangkan. Hasil dapatan ini memperlihatkan bagaimana komponen Model Penilaian KIPP berfungsi dalam menjawab persoalan kajian yang telah dikemukakan. Oleh itu, hasil dapatan melalui komponen konteks telah menjelaskan bahawa terdapat tiga perkara yang berkaitan dengan kekangan masalah pelajar dan pengajar dalam amalan pentaksiran iaitu kesukaran dalam menentukan jawatan kerja produksi Bangsawan, komitmen pelajar dalam pentaksiran produksi Bangsawan dan kriteria pemarkahan dalam produksi Bangsawan. Manakala menerusi hasil dapatan komponen input pula mendapati bahawa terdapat tiga peringkat aktiviti pentaksiran yang melibatkan pecahan kepada praproduksi, produksi dan pascaproduksi. Melalui peringkat praproduksi, pelajar akan ditaksir berdasarkan tiga komponen iaitu proses latihan dan amali, pembentangan gerak kerja produksi dan penilaian awal persembahan. Manakala di peringkat produksi, terdapat tiga juga komponen yang terlibat iaitu prapersiapan persembahan, persembahan dan selesai persembahan. Terakhir sekali adalah peringkat pascaproduksi yang melibatkan dua komponen pentaksiran iaitu laporan portfolio dan pemurnian. Seterusnya melalui komponen proses di dalam Model Penilaian KIPP, hasil dapatan kajian telah mendapati bahawa penggunaan rubrik produksi Bangsawan perlu disemak semula atas faktor ketidakseimbangan pengukuran dari segi kandungan rubrik, kejelasan rubrik, keadilan rubrik dan praktikaliti rubrik. Hasil dapatan di peringkat proses ini adalah berdasarkan pandangan pakar bidang yang berkelayakan secara teori mahupun praktikal. Komponen terakhir di dalam hasil dapatan kajian melalui Model Penilaian KIPP adalah produk. Penilaian produk tertumpu kepada hasil amalan pentaksiran bagi kursus produksi Bangsawan. Penilaian tersebut melihat kepada matlamat dan objektif bagi setiap peringkat pentaksiran yang ingin dicapai pada akhir kursus. Justeru itu, kajian ini mendapati bahawa ketiga-tiga peringkat pentaksiran di dalam aktiviti perancangan produksi, perlaksanaan persembahan dan pendokumentasian produksi telah mampu memperlihatkan keseimbangan terhadap aras kesukaran dan pemikiran pelajar. Oleh itu pengkaji mendapati bahawa aras penguasaan taksonomi bloom pada ketiga-tiga peringkat adalah seimbang dari segi domain kognitif, afektif dan psikomotor.

Oleh yang demikian hasil dapatan kajian juga mendapati bahawa wujud bias di dalam amalan pentaksiran yang melibatkan pelajar, pengajar dan dokumen pentaksiran. Justeru itu, cadangan penambahbaikan boleh dilakukan berdasarkan hasil dapatan yang diperoleh. Cadangan pertama, pelajar diberikan pilihan untuk satu jawatan kerja produksi sahaja dan tidak ada kerja tambahan dilakukan. Manakala pengisian jawatan kerja yang lain dibuat secara terbuka iaitu audition kepada pelajar luar dari kursus tersebut. Perkara ini mengurangkan bebanan kerja pelajar. Kedua, penggunaan kuliah lebih masa bagi produksi Bangsawan adalah tertakluk kepada budi bicara pelajar dan pengajar. Ketiga, dicadangkan supaya kriteria pemarkahan bagi pentaksiran produksi untuk bidang lakonan, muzik, tarian dan pengurusan diselarikan dan sama dari segi peratusan pemarkahan dan komponen penilaian. Perkara ini bagi mengelak 
bias dan gabungan markah yang tidak adil. Cadangan yang terakhir adalah berkaitan dengan rubrik produksi Bangsawan yang memerlukan semakan dan ubah suai berdasarkan pandangan pakar bidang melalui analisa kriteria Metarubrik. Pengkaji mendapati bahawa rubrik produksi Bangsawan perlu realistik, boleh diukur dan menepati bidang kerja yang ditaksirkan.

\section{Rujukan}

Abdullah, N. A. V. (2009). Perkembangan dan perubahan bangsawan di Sarawak, 1914-2004 [Doctoral dissertation, Universiti Sains Malaysia]. http://eprints.usm.my/id/eprint/10339

Arter, J. \& McTighe, J. (2001). Scoring rubrics in the classroom: Using performance criteria assessing and improving student performance. Corwing Press, Inc.

Bloom, B. (Ed.). (1956). Taxonomy of educational objectives: The classification of educational objectives. Longmans, Green and Co. Ltd.

Chapman, C. \& King, R. (2012). Differentiated assessment strategies, one tool doesn't for all. Corwin.

Deenerwan, M. (2018). Mengetahui dan menguasai pengalaman: Sebuah proses pelaksanaan penyelidikan berasaskan persembahan. My symposium on practice as research 'Practitioner's Mind' MySPAR 2018, 1, 13-26.

Frederiksen, J. R., \& Collins, A. (1989). A system approach to educational testing. American Educational Research Association, 18(9), 27-32. https://doi.org/10.3102/0013189X018009027

Gazdik, M. A. (2009). Use of rubrics as an assessment tool. Focus on Microbiology Education, 15(2), 9-11.

Hanafi, N. M. (2016). Pembangunan dan penentusahan rubrik pentaksiran prestasi bagi mentaksir projek reka bentuk seni bina di politeknik Malaysia [Doctoral dissertation, Universiti Pendidikan Sultan Idris]. http://eprints.uthm.edu.my/id/eprint/9135/

Howard, J. (2007). Curriculum development, centre for the advancement of teaching and learning. Elon University.

Idris, N. (2010). Penyelidikan dalam pendidikan. McGraw Hill (Malaysia) Sdn Bhd.

Ishak, R. (2014). Model pengajaran Bangsawan berasaskan teknologi digital di sebuah akademi seni [Master's thesis, Universiti Malaya].

Lembaga Peperiksaan Malaysia. (2000). Manual pengguna bagi guru matapelajaran, sistem pengurusan pentaksiran berasaskan sekolah (SPPBS). Kementerian Pelajaran Malaysia.

Malaysian Qualification Agency. (2014). Garis panduan amalan baik: Penilaian pelajar. MQA Publication.

McMillan, J. H. (2000). Fundamental assessment principles for teachers and school administrators. Practical Assessment, Research, and Evaluation, 7. https://doi.org/10.7275/5kc4-jy05

Moskal, B. M. (2003). Recommendations for developing classroom performance assessments and scoring rubrics. Practical Assessment, Research \& Evaluation, 8(14). https://scholarworks.umass.edu/pare/vol8/iss1/14

Othman, R. \& Awang, M. I. (2018). Analisis pentaksiran kemahiran insaniah menggunakan rubrik terhadap amalan pensyarah: Satu kajian rintis. e-Jurnal Penyelidikan dan Inovasi, 5(1), 140-158. http://rmc.kuis.edu.my/jpi/wp-content/uploads/2018/03/140-158-Rusmawati.pdf

Ozaki, C.C., Worley, D., Cherry, E. (2015). Assessing the work: An exploration of assessment in the musical theatre arts. RPA Journal, Research and Practice in Assessment, 10, 12-24. http://www.rpajournal.com/dev/wpcontent/uploads/2015/06/A2.pdf

Payne, D. A. (2003). Applied educational assessment. Wadsworth Thomson Learning.

Piaw, C. Y. (2011). Kaedah dan statistik penyelidikan: Kaedah penyelidikan. McGraw-Hill Education.

Salleh, A. S. (2003). Improvisasi dalam teater Bangsawan. Wacana Seni: Jurnal of Arts Discourse, 2, 31-44.

Stiggins, R. J. (2006). Assessment for learning: A key motivation and achievement. Edge, 2(2), Phi Delta Kappa International.

Stufflebeam, D. L, \& Coryn, C. L. S. (2014). Evaluation theory, model, and applications. Jossey-Bass \& Pfeiffer Imprints, Wiley.

Thambu, N. (2014). Penggunaan teater forum dalam pengajaran dan pembelajaran pendidikan moral di sekolah menengah [Doctoral dissertation, Universiti Malaya]. http://studentsrepo.um.edu.my/4708/1/ Nadarajan._Teater_Forum.pdf 